\title{
WHEN DISASTER STRIKES - A CASE LAW ANALYSIS OF SIMULTANEOUS DEATHS
}

\author{
MC Schoeman-Malan \\ $B A$ (Law) LLB LLD \\ Professor of Law \\ University of Pretoria
}

\section{SUMMARY}

Incidents of loss of life might inevitably result in litigation when the sequence of victims' deaths is disputed. In this contribution, an analysis and discussion of tragic incidents and case law dealing with simultaneous deaths as well as the questions posed by the law of succession by the "commorientes" doctrine are done. The potential impacts where simultaneous deaths occur and several family members, or related persons, die instantly, are illustrated, with reference to natural disasters and shared tragedies on the one hand, and the frequency of the simultaneous loss of lives on the other. Different scenarios found in numerous reported incidents and cases from South Africa and other jurisdictions are discussed.

It is also shown that several aspects have contributed to the recent increase of simultaneous deaths due to the change in times and conditions over the past 2000 years. Also contributing to this is the facts of the case, on the one hand, and dissimilarity in the approaches between common law and civil law on the other. The author focuses on case law as the Courts are called upon to determine the order of deaths to establish whether the exact sequence can be determined, or not. It has become apparent that whenever the order of death can be established accurately, the distribution of the estates will follow the sequence of deaths. However, if the order cannot be established the departed are either "regarded" as having predeceased each other (as no one survives the other), or surviving each other resulting in them being incapable of inheriting from one another. South Africa is exposed to high rates of simultaneous deaths, especially road accidents, murders and attacks on civilians, and despite daily media reports of people dying in the same disaster, there has been only a hand full of reported Court cases on this topic.

\section{$1 \quad$ INTRODUCTION}

The death of any person is mourned and when a family or more than one member of a family pass away in the same accident or disaster, the agony is overwhelming and inconceivable. Throughout history, thousands of families or members of families have lost their lives in natural disasters, ${ }^{1}$ during wars

Josef "25 Worst Natural Disasters Ever Recorded" 26 August 2013 Science \& Technology http://list25.com/25-worst-natural-disasters-recorded/4/ (accessed 2015-09-28); see Conway and Bertsche "The New York Simultaneous Death Law" 194413 Fordham LR 17 explain: "A global war of the kind now being fought will inevitably result in a great many deaths, the time of which will be unascertainable". 
or in other catastrophes. ${ }^{2}$ In recent years, politically inspired incidents of terrorist attacks on innocent civilians have shocked mankind and have led to related people being killed simultaneously. ${ }^{3}$ Where simultaneous deaths occur and several family members, or related persons, die instantly, it potentially impacts directly on the distribution of the estates of people involved. These incidents of loss of life might inevitably result in litigation when the sequence of victims' deaths is disputed. ${ }^{4}$

Although there are only a handful of reported South African cases that deal with simultaneous deaths, ${ }^{5}$ there appears to be a growing number of disputes globally where people have died due to a single catastrophe. This problem can arise regardless of whether related heirs leave wills or die intestate. ${ }^{6}$ It has become a widespread practice for couples or relatives to provide for possible unforeseen subsequent deaths by inserting so-called "common calamity" clauses in their wills. ${ }^{7}$ These clauses prove not to be problematic where the testators of such wills have the same contingency substitutes (heirs) and the wills are mirror images of one another. ${ }^{8}$ But, if either or both testators have separate (different) beneficiaries such a clause might have an effect opposite to what was foreseen by the testators. ${ }^{9}$ If one

2 Rickards "10 Deadliest World Events in Human History" 3 January 2013 Listverse explains: "Throughout human history, there have been many world events that have seen a multitude of deaths and widespread destruction"; see also Aggrawal "Mass Murder" 20053 Encyclopedia of Forensic and Legal Medicine 216ff.

3 McHugh "Causes of 2011 Syrian Civil War: Timeline of Five Years of Airstrikes, Bombings, Key Dates and Events" 14 March 2016 International Business Times; modern day terrorist attacks, where multiple people were killed, include the terrorist attack by Al-Qaeda on the Twin Towers in New York in 2001, the 2014 Malaysian aircraft MH17 that was shot down by a surface-to-air missile; see Gjorgievska "The Lives Lost in the MH17 Disaster" 21 July 2014 Time; News reported "Paris Attacks: Bataclan and Other Assaults Leave Many Dead" 14 November 2015 and News reported "Paris Attacks: Who Were the Victims? 19 November 2015 BBC News; Contributor "Brussels Attacks: Zaventem and Maelbeek Bombs Kill Many" 22 March 2016 BBC News; Rickards 3 January 2013 Listverse.

4 See Tracy and Adams "Evidence of Survivorship in Common Disaster Cases" 194038 Michigan LR 801 for "common disaster"; Corbett, Hofmeyr and Kahn The Law of Succession in South Africa 2ed (2001) 4-5 and 547; De Waal and Schoeman-Malan Law of Succession 5ed (2015) 12; see Aggrawal 20053 Encyclopedia of Forensic and Legal Medicine 216ff; Josef http://list25.com/25-worst-natural-disasters-recorded/4/.

5 Nepgen v Van Dyk 1940 EDL 123; Ex parte Martienssen 1944 CPD 139; Ex parte Chodos 1948 (4) SA 221 (N); see also Roeleveld "Questions Concerning Simultaneous Deaths" 1970 Acta Juridica 31 33; Schoeman "Commorientes in Heroënskou" (Commorientes Reconsidered) 1999 De Jure 108109.

6 Estate of Villwock v Olinger 142 Wis 2d 144, 418 N W 2d 1 (1987) (Wisconsin Court of Appeals); Matter of Estate of Campbell 641 P 2d 610 (1982) 56 or App 222.

7 See Corbett et al The Law of Succession in South Africa 547-548. This type of clause is also known as the Titanic-clause. See Cussen "Protect your Estate Plan with a 'Titanic' Clause" 30 January 2017 https://www.fool.com/investing/2017/01/30/protect-your-estateplan-with-a-titanic-clause.aspx (accessed 2017-02-16). Even the most carefully crafted estate plan can go awry in certain circumstances.

8 See also Greyling v Greyling 1978 (2) SA 114 (T); Murray "Law of Succession (including Administration of Estates)" 1978 Annual Survey 347364 for a detailed discussion of the Greyling case; Corbett et al The Law of Succession in South Africa 548; Orji "Simultaneity of Death and Survivorship - Law of Uncertainty and Improbability" 2013 The Conveyancer and Property Lawyer $501 \mathrm{ff}$.

9 See Estate Greenacre v Brett 1956 (4) SA 291 (N); Ex parte Graham 1963 (4) SA 145 (D); Greyling v Greyling supra; Smith v Pretorius [2012] ZAFSHC 161. 
of the testators survived the other (first dying) for a very short time it might result in the will not taking effect. ${ }^{10}$

This contribution entails an analysis and discussion of tragic incidents and case law dealing with simultaneous deaths as well as the questions posed by the law of succession by the "commorientes" doctrine. ${ }^{11}$ The frequency of simultaneous loss of lives will be illustrated with reference to natural disasters and shared tragedies. The impact of simultaneous deaths on the administration and distribution of multiple estates will be evaluated, based on different scenarios found in the numerous reported incidents and cases from South Africa and other jurisdictions. ${ }^{12}$

\section{NATURAL DISASTERS AND OTHER COLLECTIVE (SHARED) TRAGEDIES}

\section{$21 \quad$ Natural disasters}

Throughout history, natural disasters of different kinds, such as floods, earthquakes and volcanic eruptions, have led to the simultaneous demise of people. ${ }^{13}$ The likelihood and occurrence of disasters resulting in simultaneous deaths have been known since the beginning of time. ${ }^{14}$ Josef reports as follows on historical natural disasters: ${ }^{15}$

"[M]other nature certainly dishes out her fair share of damage. While there are many criteria as to what would be considered the "worst" natural disaster ranging from lives lost to cost incurred, the earthquakes, typhoons, and tsunamis you are about to witness are all horrific in their own right."

Global warming and threats of ozone damage, apparently contribute to natural disasters, which seem to occur more frequently in the $21^{\text {st }}$ century

10 Tracy and Adams 194038 Michigan LR 806; Nathan "Common Disasters and Common Sense in Louisiana" 1966-1967 Tulane LR 40; Gallanis "Death by Disaster: AngloAmerican Presumptions, 1766-2006" in Helmholz and Sellar (eds) The Law of Presumptions: Essays in Comparative Legal History (2009) 189-200.

11 The doctrine of "commorientes" is discussed in an article to be published in 2017 De Jure.

12 The consequences of simultaneous deaths were recently draw attention to by Van Mourik in "Column Roland van Mourik - A Legal Perspective on MH17" 25 Sept 2014 Nijmegen Business. He speaks out with grief and anger expressing his shock, about the absurd and tragic loss of lives. He states: "As a notary, you are regularly involved in the death of one person. If a whole family dies at the same time (simultaneously), it is extremely rare and the notary will have to deal with multiple estates simultaneously" (own translation).

13 Recently several earthquakes hit Italy, see "Another Deadly Earthquake Hits Northern Italy" 18 January 2017 The Telegraph.

14 See The Holy Bible in Genesis 7 verse 11: "In the six hundredth year of Noah's life, on the seventeenth day of the second month - on that day all the springs of the great deep burst forth, and the floodgates of the heavens were opened. And rain fell on the earth forty days and forty nights."

15 Josef http://list25.com/25-worst-natural-disasters-recorded/4/ He refers inter alia to the Antioch earthquake (526); Spanish influenza (1918); the Black Death (1348); Gujarat earthquake (2001); Haiti earthquake (2010); Cyclone Nargis (2008); Pakistan earthquake (2005); Indian Ocean earthquake (2004); New Zealand earthquake (2011) and the Mozambique flood (2000). 
than before. ${ }^{16}$ Goldberg indicates that disasters, including storms, floods and heat waves have increased fivefold since the 1970's. Recent natural catastrophes which have caused numerous simultaneous deaths include tsunamis, ${ }^{17}$ hurricanes, ${ }^{18}$ earthquakes ${ }^{19}$ and volcanic eruptions. ${ }^{20}$

In all these natural disasters, several members of the same family, or even generations of related people, lost their lives simultaneously or shortly after one another. In older case law, such as Taylor $v$ Diplock, ${ }^{21}$ Sillick $v$ Booth, ${ }^{22}$ Underwood $v$ Wing ${ }^{23}$ and Wing $v$ Angrave, ${ }^{24}$ disputes arose relating to simultaneous deaths, mostly due to storms at sea. In Cowman $v$ Rogers a whole family died in a devastating flood. ${ }^{25}$ However, in recent times natural disasters have not necessarily given rise to controversy and inheritance disputes. ${ }^{26}$

\section{Shared tragedies}

Other shared tragedies, on the contrary often result in estate disputes. ${ }^{27}$ Most of the disasters the world has witnessed over the last centuries are typically man-made, being the result of wars and terrorism. ${ }^{28}$ Terrorist groups have in recent times, targeted public spaces to kill many civilians instantaneously to obtain their political aims. ${ }^{29}$ Some of the more recent tragedies which left the families of victims devastated include the disappearance of the Malaysia Airlines flight MH370 with 277 passengers

16 Goldberg "Eight Ways Climate Change is Making the World More Dangerous" 14 July 2014 The Guardian; Oskin "2011 - Japan Tsunami Unleashed Ozone-destroying Chemicals" 3 April 2015 Live Science.

17 Contributor "10 Deadliest Tsunamis in Living Memory" undated http://brainz.org/10-mostdevastating-tsunamis-recent-history/ (accessed 2016-02-24); Oskin 3 April 2015 Live Science.

18 See Zimmermann "Hurricane Katrina: Facts, Damage \& Aftermath" 20 August 2012 Live Science.

19 Shrestha, Sanchez and Drash "Earthquake Slams Nepal; Devastating Loss of People" 27 April 2015 CNN News.

20 Bloom and Frymann: "Volcano Eruption Kills at Least 16 People in Indonesia as Ash is Sent Spewing Several Miles into the Air" 2 February 2014 Daily Mail.

212 Phillimore's Ecclesiastical Reports 261 267; 161 Eng Rep Repr 11371140 (1815).

22 (1841) 62 Eng Rep 1137

23 (1855) 4 De G M \& G 633.

24 (1861) 8 HLC 183.

25 Cowman v Rogers 73 Md 403; 21 At Rep 64 (1891).

26 See also Tracy and Adams 194038 Michigan LR 809; Gallanis in Helmholz and Sellar (eds) The Law of Presumptions 190-191; De Colyar "Notes on the Presumptions of Death and Survivorship in England and Elsewhere" 1911 Journal of the Society of Comparative Legislation 255-277.

27 Parsons "Titanic Witnessed Mankind at its Heroic Best and Selfish Worst" 14 April 2012 http://www.mirror.co.uk/news/uk-news/tony-parsons-titanic-witnessed-mankind-794758 (accessed 06-01-2017).

28 News reporter 19 November 2015 BBC News; Contributor 22 March 2016 BBC News.

29 Aggrawal 20053 Encyclopedia of Forensic and Legal Medicine 216-223; see also Hooton "Malaysia Airlines Crash: Family who Lost Two Members on Flight MH370 have Lost Two More on MH17" 18 July 2014 Independent. 
and two crew members on board and the Malaysia Airlines flight $\mathrm{MH} 17$ that was shot down in the Ukraine.

Collective tragedies often result in victims dying due to the same misfortune. ${ }^{31}$ The world was stunned when the Titanic sank in 1912 and several husbands and wives and other family members died as a result. The fate of one family aboard the Titanic was reported on as follows: ${ }^{32}$

"So it was then that the night of Sunday $14^{\text {th }}$ April at $11.40 \mathrm{pm}$ when the iceberg hit the Titanic that Frederick Goodwin and his sons, Charles who was fourteen, William who was eleven and Harold who was nine years old were asleep in the bow on the ship when the Titanic started to sink. His wife Augusta Goodwin was asleep in the stern of the ship with her daughters Lillian who was sixteen years old and Jessie who was ten. Also, sleeping with his mother was baby Sidney Goodwin who was a year and seven months old."

Other disastrous incidents include motor vehicle accidents, ${ }^{33}$ plane crashes, ${ }^{34}$ fires, ${ }^{35}$ massacres, ${ }^{36}$ shipwrecks, ${ }^{37}$ exploding bombs $^{38}$ and

30 Gjorgievska 21 July 2014 Time: "A total of 298 lives - including over 20 families and as many as 80 children - were lost when flight MH17 was apparently downed by a surface-toair missile on Jul. 17"; see also Van Mourik 2014 Nijmegen Business; McGarr "Kaczynski Crash" 13 April 2010 http://www.mcgarrsolicitors.ie/2010/04/13/kaczynski-crash/ (accessed 2016-11-23) reports that President Kaczynski of Poland who died with his wife in the Smolensk air accident could be called "commorientes".

31 Tracy and Adams 194038 Michigan LR 802 and 824; Nathan 1966-1967 Tulane LR 42 opines that simultaneous deaths have increased in thousand-fold; see also Trushin "Simultaneous Death Laws in Florida" 30 August 2013 Florida Probate Lawyer; Parsons http://www.mirror.co.uk/news/uk-news/tony-parsons-titanic-witnessed-mankind-794758.

32 Parsons http://www.mirror.co.uk/news/uk-news/tony-parsons-titanic-witnessed-mankind794758; Contributor "The Goodwin Family Died on the Titanic" updated 24 December 2016 Hubpages http://hubpages.com/education/Goodwin-family-Titanic-1912-children-diedunknown -child-Sidney-Family-England-100-years-ago (accessed 2017-01-06).

33 Nepgen v Van Dyk supra; Gray v Sawyer 247 SW 2d 496497 (Kentucky Ct Ap 1952); White $v$ Taylor 286 South Western 2d 925 (Texas 1956); Estate of Rowley Cal App 2d 324 332-335 [65 California Law Reporters 139] (1967); Estate of Schmidt 261257 California Court of Appeal 2d 262 (1968); Re Fair 12 Dominion Law Reports 3d 755 (1971 NS); 17 DLR 3d 751; Collins v Becnel 297 So 2d 506 (Court of Appeal of Louisiana Fourth Circuit 1974; Greyling v Greyling supra; Estate of Villwock v Olinger supra; Re Kennedy [2000] 2 Ireland Reports 571; Tucker v Shreveport Transit Management Inc. Louisiana Civil Court 226 F 3d 394 CA, $5^{\text {th }}$ Circuit 2000; Estate of Nancy Schweizer v Estate of Roland 7 Kan App 2d 128 (1981); 638 P 2d 378; in the Estate of Graham William Dawson (deceased) and Teresa Veronica Dawson (deceased) [2016] SASC 89.

34 See Sherman v Roe 262 S W 2d 393395 (Supreme court of Texas 1953); Ex parte Graham supra; Estate of Meade California Court of Appeal [Civ No 295 Fifth Dist June 24 [1964]; Smith $v$ Pretorius supra.

35 In Re Smith [1955] New Zealand Law Reports 1122; [1956] 992; Lamb v Lord Advocate 1976 Session cases (Scotland) 110.

36 News reporter "Nepal Royal Family Massacred" 2 June 2001 BBC News; Constable "Prince Kills 8 in Nepal's Royal Family; Suicide Rampage Linked to Dispute over a Bride" 2001 Washington Post; see also $S$ v DD [2014] ZANCHC 8 where a son murdered his family and where there was no family member to inherit the estates.

37 Taylor v Diplock supra; Sillick v Booth supra; Underwood v Wing supra; Wing v Angrave supra; Re Rowland: Smith v Russell [1963] Ch 1 (CA) 11.

38 Ex parte Martienssen supra; Hickman v Peacey [1945] Appeal Case (AC) 304; In re Pringle [1946] Ch 124; Ex parte Chodos supra. 
poisoning, ${ }^{39}$ to name but a few. It was reported that the recent tragic incident, where a Germanwings aircraft crashed in the Alps, claimed the lives of three generations of one family. ${ }^{40}$

\section{SIMULTANEOUS DEATH OF POTENTIAL BENEFICIARIES}

People who died simultaneously are known as "commorientes". ${ }^{41}$ The word is a broad concept and includes people who die together or die due to the same catastrophe, and also those who die in circumstances where it is uncertain who died first and who survived. ${ }^{42}$ From a law of succession perspective the words "simultaneous death" might differ in meaning from what the average person would consider it to mean (that is, that people died at the same time or as a result of the same event). ${ }^{43}$ From a medical perspective ${ }^{44}$ the words have a meaning that differs from that they are understood to mean for purposes of a legal enquiry. ${ }^{45}$ Belkin explains that under the common law cardiorespiratory standard of death, a person theoretically survives another if his or her heart beats once more than that of the decedent. ${ }^{46}$ For purposes of the law of succession, it is accepted that death means "brain stem death". It is, however, possible from a medical

39 Re Bate [1947] 2 All ER 418; Ross's Judicial Factor v Martin [1955] SC (House of Lords) 56; Adare v Fairplay [1956] OR 188 (Court of Appeal for Ontario) where a couple died together in their house from carbon monoxide poisoning; Re Trenaman [1962] SASR 95; Janus $v$ Tarasewicz 135 Illinois Court of Appeals 3d 936, 482 NE 2d 418 III 1985; Leete $v$ Sherman 290 Michigan App 647803 NW2d 889 (2010).

40 See also Dawber "Germanwings Crash: Three Generations From Same Spanish Family Killed in Alps Disaster" 30 March 2015 The Independent; see also Ex parte Graham supra; Smith v Pretorius supra $§ 4$.

41 Corbett et al The Law of Succession in South Africa 4-5 and 547; De Waal and SchoemanMalan Law of Succession 12.

42 Corbett et al The Law of Succession in South Africa 5; Nathan 1966-1967 Tulane LR 39.

43 De Beer Simultaneous Death: Arbitrary Fact (LLM Dissertation NWU 2012) 6.

44 Belkin Death Before Dying: History, Medicine and Brain Death (2014) 100101 . Some of the modern studies emphasize spontaneous respiration as an indication that a person is alive.

45 See Capron and Kass "A Statutory Definition of the Standards for Determining Human Death: An Appraisal and a Proposal" 1972 University of Pennsylvania LR 87 and 89-90; Finch and Wallis "Death, Inheritance and the Life Course" 1992 The Sociological Review 50-68; Wijdicks "The Neurology of Death and What it Does Not Mean" 3 June 2014 http://dx.doi.org/10.1093/brain/awu124 (accessed 2015-11-25); the South Africa National Health Act 63 of 2003.

46 Belkin Death Before Dying 100. 
perspective to prove that people died seconds apart. ${ }^{47}$ In Thomas $v$ Anderson $^{48}$ it was explained that:

"Death occurs precisely when life ceases and does not occur until the heart stops beating and respiration ends. Death is not a continuous event and is an event that takes place at a precise time."

\section{DISPUTES OVER ORDER OF DEATH}

To illustrate the complexity of estate disputes dealing with the order of death, the South African case of Smith $v$ Pretorius ${ }^{49}$ serves as a good example. In this case, legal action was instituted after a plane crashed into the Drakensberg killing both son (the pilot) and mother (the passenger). ${ }^{50}$ It was argued that despite the impact, forces and speed involved when the plane crashed into a mountain, the one victim (that is, the mother) survived the other (that is, the son) for only a split second because she sat in the seat behind him.

From a law of succession point of view, the problem that presents itself in a common disaster is to determine the sequence of the victims' (who are related to one another or potential beneficiaries of one another), deaths. ${ }^{51}$ The exact order of their deaths will direct the distribution of the estates of those involved. A uniform principle of succession law is that if a beneficiary does not survive the deceased (that is, is predeceased), in the absence of a contrary directive in the will or the operation of a rule of law, the benefit to the beneficiary lapses and falls back into the testator's estate. ${ }^{52}$ West explains as follows: ${ }^{53}$

"A beneficiary who predeceases or dies simultaneously with the testator acquires no rights, nor does his or her estate or heirs, unless the will provides to the contrary (see Ex parte Wessels and Venter NNO: In re Pyke-Nott's Insolvent Estate 1996 (2) SA 677 (O))."

47 Re Johannisse and Gray (1985) 33 ACWS (2d) 231 determined brain death to constitute death, for legal purposes; Belkin Death Before Dying 100 states: "Brain death-the condition of a non-functioning brain, has been widely adopted around the world as a definition of death since it was detailed in a Report by an Ad Hoc Committee of Harvard Medical School faculty in 1968"; see also Boezaart Law of Persons (2016) 17 and 154-155; De Beer Simultaneous Death: Arbitrary Fact 25; Wijdicks http://dx.doi.org/10.1093/brain/awu124; Phillips "Time of Death: Does it Matter?" 2010 California Law Journal: "In California, an individual is dead when he or she has sustained either (1) irreversible cessation of circulation and respiratory functions, or (2) irreversible cessation of all functions of the entire brain, including the brain stem."

481950215 P 2d 478 (California District Court of Appeals).

49 [2012] ZAFSHC 161.

50 De Beer Simultaneous Death: Arbitrary Fact $6 \mathrm{ff}$; see also In the Estate of Graham William Dawson (deceased) and Teresa Veronica Dawson (deceased).

51 Corbett et al The Law of Succession in South Africa 547.

52 See De Colyar 1911 Journal of the Society of Comparative Legislation 255-277; Tracy and Adams 194038 Michigan LR 181ff; Conway and Bertsche 194413 Fordham LR 19-20; Corbett et al The Law of Succession in South Africa 547.

53 West "Simultaneous Death" 21 May 2015 Ghostdigest. 
If a beneficiary (victim), however, survives the testator, even by only a short period of time, the survivor can inherit from the first dying. ${ }^{54}$ It means that when more than one person perishes alongside each other, the estate of the first dying deceased can vest in the second deceased in terms of testate- or intestate succession. It can then be distributed through the second deceased's estate to his or her heirs. This will result in a situation where the beneficiaries or heirs of the "survivor's estate", rather than those of the (first dying) testator, will enjoy that benefit.

The matter of establishing the sequence of death by the Court literally becomes a matter of "life and death". ${ }^{56}$ The Courts have to determine who had died first (and at exactly what time) and who had survived. To establish the exact moment and consequent order of the deaths of the different victims remains a factual question. ${ }^{57}$ Capron and Kass explain as follows:

"The right to a portion of the testator's estate therefore depends upon the beneficiary surviving the deceased. When several people related to one another die together, survivorship will1e to 
There are three different approaches to address the intricate question of people dying together. ${ }^{61}$ These approaches apply when uncertainty arises as to the sequence of deaths. ${ }^{62}$ The first approach is the presumption that one party had survived. ${ }^{63}$ The second is the presumption that the deaths had occurred simultaneously. ${ }^{64}$ The third is the so-called no presumption rule where the question of who had passed away first is a factual one ${ }^{65}$ Despite the differences in these approaches, all cases are subject to the facts being scrutinised by the Courts to establish whether there was a possible survivor (even if for only a very short time). ${ }^{66}$

In addition to the theoretical variances in the approach in the civil law and common law towards "commorientes", case law can also be divided into three different situations based on the factual circumstances surrounding the deaths of people. To illustrate the factual differences in case law, three possible scenarios, will be considered.

- The first scenario is when the deceased people did not, in fact, die at exactly the same time (there is evidence that one deceased survived the other).

- The second is when the deceased did die at exactly the same time. ${ }^{68}$

- The last scenario is where it is not possible for the Court to come to a positive conclusion (that is, whether there was either simultaneously deaths or possible survivorship).

The latter situation pertains where there is insufficient evidence or no evidence of the order of death. ${ }^{69}$ The facts, on the one hand, and dissimilarity in the approaches between common law and civil law on the other will influence the outcome of the division and distribution of the estates involved. These different scenarios are often interconnected, especially as regards the second and third scenarios.

factors that can contribute to the results; Crockett http://www.orangecountyestate planninglawyer-blog.com/2014/10/probate-inheritance-simultaneous-deaths/.

61 The approaches are discussed in an article to be published in $2017 \mathrm{De}$ Jure; see also Conway and Bertsche 194413 Fordham LR $18 \mathrm{ff}$ for this classification.

62 Author's own emphasis.

63 The civil law approach; Tracy and Adams 194038 Michigan LR 804; Roeleveld 1970 Acta Juridica 42; Derrett "Commorientes" 1977 University of Ceylon Review 55ff.

64 Derrett 1977 University of Ceylon Review 57; Continental law simplification of the Roman law.

65 This approach is followed in South Africa; see Roeleveld 1970 Acta Juridica 31ff; De Colyar 1911 Journal of the Society of Comparative Legislation 255-277; Corbett et al The Law of Succession in South Africa 5.

66 In the Estate of Graham William Dawson (deceased) and Teresa Veronica Dawson (deceased).

67 Tracy and Adams 194038 Michigan LR 812 fn 80; Corbett et al The Law of Succession in South Africa 4-5 and 547.

68 Corbett et al The Law of Succession in South Africa 547.

69 See Roeleveld 1970 Acta Juridica 49 for circumstances that can contribute to the judgment. 


\section{Related people did not die at the same time}

As seen above, the general principle of the law of succession is that when it is possible to establish that one person had, in fact, survived another, the estates of the deceased would be distributed in the order of the deaths of the departed. ${ }^{70}$ Theoretically (in the context of "commorientes"), if there is evidence of survivorship the departed (victims) cannot be said to have died simultaneously. The estate of the first dying falls open (the moment he or she dies) and the survivor would succeed to the first dying, but the first dying cannot succeed to the survivor. ${ }^{71}$ When the "survivor" subsequently passes away (even if it is only a second later) the "survivor's" estate, including that which he or she has inherited from the first dying, devolves to his or her beneficiaries. $^{72}$ Whenever the order of death can be established, any uncertainty falls away and the division of the estates will follow the sequence of deaths.

The case of Estate of Rowley illustrates how technical and scientific evidence can influence the outcome of a case. ${ }^{74}$ In this case, two unrelated women (friends, $\mathrm{R}$ and $\mathrm{C}$ ) were killed in a high-speed automobile accident. $\mathrm{C}$ was the beneficiary in the will of R. The executor of R's estate alleged that $R$ and $\mathrm{C}$ either died at the same time or that there was insufficient evidence to establish who had died first. C's executor opposed this petition, arguing that $\mathrm{C}$ had, in fact, survived $\mathrm{R}$ and, therefore, was entitled to take under R's will. As the witnesses testified that $R$ died first by a fraction of a second because the right side of the car where $\mathrm{R}$ was sitting, was struck first, it was accepted that $C$ had survived and could inherit from $R$. ${ }^{75}$

Another case where rather peculiar facts demonstrate the dilemma that can arise when the sequence of deaths is questioned, is Janus $v$ Tarasewicz. $^{76}$ This unfortunate turn of events occurred, when one A purchased a bottle of Tylenol capsules which had been poisoned. He took it and it led to his passing. ${ }^{77}$ The deceased's brother and sister-in-law, not knowing what had caused A's death, also took some of the contaminated

70 Orji 2013 The Conveyancer and Property Lawyer 506-507; Schoeman 1999 De Jure 110.

71 See Smith v Pretorius supra; Contributor "Notes on Recent Cases" 81943 Cambridge Law Journal 215; Corbett et al The Law of Succession 4-5; Phillips 2010 California Law Journal; Orji 2013 The Conveyancer and Property Lawyer 505.

72 Corbett et al The Law of Succession in South Africa 547; see also Re Lindop, Lee-Barber v Reynolds [1942) Ch 377; Ross's Judicial Factor v Martin supra; Estate of Villwock v Olinger supra; Matter of Estate of Hughes.

73 Author's own emphasis; see also Gallanis in Helmholz and Sellar (eds) The Law of Presumptions 198.

74 It was also argued in Smith $v$ Pretorius supra (above) that the mother survived her son with seconds.

75 If they had died simultaneously $C$ could not inherit from $R$. Evidence on the sequence of deaths include statements of the coroner that the direction of force was from right to left and of necessity must have affected R first. See also Tracy and Adams 194038 Michigan LR 813-814 and 821.

$76 \quad 1985$ Illinois Court of Appeals.

77 See Ryan "The Uniform Determination of Death Act: An Effective Solution to the Problem of Defining Death" 1982 Washington and Lee LR 1517-1518; Orji 2013 The Conveyancer and Property Lawyer 506. 
capsules. They instantly became ill and were taken to the hospital. The brother was pronounced dead on arrival but his wife remained in a coma for a while before she was pronounced dead. She had factually survived her husband and the latter's estate vested in her and led to her family inheriting life insurance that her husband had taken out on her life. The case illustrates both the inherent difficulties in establishing the exact moment of death and the discrepancy in the way the law handles the devolution of assets which variously pass under wills, intestacy, joint tenancy and life insurance. ${ }^{78}$ Because there was "sufficient evidence" of survival, the rule of survivorship (in Illinois) did not apply, even though it meant the property of the husband, would pass through his wife's estate. ${ }^{79}$ This case was widely criticised. ${ }^{80}$

In the Estate of Schmidt, a husband and wife were killed in a high-speed head-on collision. ${ }^{81}$ The Court, after hearing evidence of numerous lay and expert witnesses, ruled that there was "sufficient evidence" that the wife had survived her husband by ten to twenty minutes. ${ }^{82}$ In the Estate of Villwock, a couple was involved in a car accident. ${ }^{83}$ While they were being transferred to hospital, the husband's heart and lungs failed. He left his estate to his wife without a contingency in the event that she predeceased him. The will of the wife had left her estate to her family members. They had no children together, but he had a daughter from a previous marriage. The daughter argued that her father and his wife died simultaneously and that the estate of her father should be distributed as if his wife had predeceased him. Evidence was that his heart and lung failure in the ambulance was irreversible. The Court ruled on the facts that he died before his wife and that his estate, therefore, passed through his wife. In Gray $v$ Sawyer the Court accepted the following evidence on survival: ${ }^{84}$

"Realistically, a person is dead when there has been a complete decapitation of the head, as was proved in the original case; but upon a hypothetical question submitting the above statements of Mrs Hickey and, as well, the terrific mangling of the body of her husband and other conditions relating to both, several doctors expressed the opinion that Mrs Gugel had survived her husband for a fleeting moment. The doctors told the court that a body is not dead so long as there is a heartbeat and that may be evidenced by the gushing of blood in spurts. This is so though the brain may have quit functioning."

78 These aspects are discussed in more detail in another publication. See Mee "Commorientes, Joint Tenancies and the Law of Succession" 2005 Northern Ireland Legal Quarterly $171 \mathrm{fn} 1$.

79 Gallanis in Helmholz and Sellar (eds) The Law of Presumptions 198 explains: "This led to gruesome and undesirable results in cases like Janus $v$ Tarasewicz".

80 Phillips 2010 California Law Journal; Gallanis in Helmholz and Sellar The Law of Presumptions 197ff for a discussion of the case. The USDA was promulgated in 1991 and amended in 1993 in a response to the Janus case.

81 Estate of Schmidt 1968 California Court of Appeal.

82 See Matter of Estate of Hughes.

83 Estate of Villwock $v$ Olinger supra. At the hospital, both were kept alive for about an hour, but they were eventually pronounced dead.

84 Gray v Sawyer supra. 
It has become evident that the Courts sometimes accept the slightest evidence (even a split second) indicating survival, to find that simultaneous deaths did not take place. ${ }^{85}$ Orji comments as follows on this: ${ }^{86}$

"Some of the cases that have proceeded on the facts of commorientes show how much uncertainty the courts are faced with. Although the measure of certainty in science may not measure up to the same in law, legal findings are not built on probability. Likelihood is opportunistic, and possibility sometimes unsatisfactory."

Although these people are referred to as "commorientes" they did not, strictly speaking, die at the same time. ${ }^{87}$

Sometimes situations, where there has been "no common calamity", are confused with simultaneous deaths. It happens that people are referred to as having died "simultaneously" when in fact the circumstances show that although they died on the same day from natural causes or otherwise, that the circumstances are not related to one another. ${ }^{88}$ An example of this scenario is where the former US presidents Thomas Jefferson and John Adams, who were once fellow patriots and then opponents, died on the same day within five hours of each other. ${ }^{89}$ In another instance, it was reported that a father and his son died simultaneously where they died on the same day but in different hospitals 200 miles apart. ${ }^{90}$ In another peculiar incident, a husband and wife died in Guruve, Zimbabwe, within less than an hour. ${ }^{91}$ It was also reported that Mr Wilson (93) and his wife (89), both Alzheimer's patients, had died within minutes of each other. They had been living in separate nursing homes for years when their son got back-to-back

85 Author's own emphasis; see also Thomas v Anderson supra; Smith v Smith 229 Ark 579 (Arkansas 1958) and Estate of Schmidt 1968 California Court of Appeal discussed by Katz and Capron Catastrophic Diseases: Who Decides What? A Psychosocial and Legal Analysis (2005) 210; see also Greyling v Greyling supra; Murray 1978 Annual Survey 364; Orji 2013 The Conveyancer and Property Lawyer $501 \mathrm{ff}$.

86 Orji 2013 The Conveyancer and Property Lawyer 503; see also Lamb v Advocate General supra and Adare $v$ Fairplay supra for a discussion of what "uncertainty" implies.

87 See Tracy and Adams 194038 Michigan LR 813 and 828; see also Estate Acord 946 F 2d 1473 (9th Cir 1991) where a spouse died 38 hours after her husband.

88 See Mee 2005 Northern Ireland Legal Quarterly 171; Stephens v Beard 428 SW 3d 385 Tyler Court of Appeals Texas [2014]. In Wing v Angrave supra 208-209 Lord Campbell referred to the hypothetical case where a husband's ship was lost at an unknown point in its voyage and his wife died at home at around the same time. See also Walker "Cold-blooded and Warm-blooded Presumptions" paper presented 10-2008 Statute Law Society Conference 2ff. See also Bennett v Peattie (1925) 57 OLR 233 where the Ontario Court of Appeal stated that: "From the standpoint of judicial inquiry, I am inclined to the view that in cases where there has been no resuscitation, death should be regarded as having taken place at the moment when respiration and pulsation ceased without entering into the inquiry that troubles biologists as to the exact line between life and death in the individual."

89 See Contributor "The Simultaneous Deaths of Thomas Jefferson and John Adams" 4 July 1826 This day in History http://www.history.com/this-day-in-history/thomas-jefferson-andjohn-adams-die.

90 See Contributor "Father, Son Die Simultaneously" 10 June 1948 http://trove.nla.gov.au/ndp/del/ article/18074071 (accessed 2015-08-12).

91 Contributor "Couple in Bizarre Death on Same Day" 17 May 2015 http://www.newsdzezimbabwe.co.uk/2015/05/couple-in-bizarre-death-on-same-day.html (accessed 2015-11-17). 
calls informing him that both his parents had died. ${ }^{92}$ In In re Ellis' Will, ${ }^{93}$ a situation arose where both spouses died of natural causes within three days of one another. Although these situations are sometimes mistakenly referred to as "simultaneous deaths", it is clear that the deceased did not die as "commorientes".

\section{Related people die at exactly the same time}

Some scholars assume that "dying at the same time" is a contradiction in terms, as two people can never momentary die at exactly the same time. ${ }^{94}$ Dollar explains that true simultaneous deaths (in instances such as an explosion or a building collapsing) are extremely rare because often forensic evidence can determine who had died first. ${ }^{95}$ The perception that persons cannot die simultaneously originates from the old common law case of Underwood $v$ Wing where Lord Cranworth observed the improbability of two persons dying at exactly the same moment. ${ }^{96} \mathrm{He}$ opined that such a finding would be based on false data. ${ }^{97}$ However, the question whether it is, in theory, possible for people to die at "exactly the same time" has occasionally come before the Courts. ${ }^{98}$ In the English case of Hickman $v$ Peacey ${ }^{99}$ the following was stated when dealing with the vexing question of simultaneous deaths: ${ }^{\text {to }}$

"[N]o doubt, when a bevy of angels is performing saltatory exercises on the point of a needle it is always possible to find room for one more, but propositions of this character appear to me to be ill suited for adoption by the law of this country which proceeds on principles of practical common sense."

If, however, it is hypothetically accepted that more than one person can die "exactly at the same time", the common law principle remains unchanged (that neither victim can inherit from the other) as they are regarded as having

92 Begley "Couple Dies within Minutes of Each Other After 73 Years of Marriage" 10 August 2015 Time.

9369 SE 2d 25 (1952) 235 North Carolina Supreme Court 27; see also Estate Acord.

94 This might stray precariously into metaphysics; see also Gray $v$ Sawyer supra; In re Pringle; Orji 2013 The Conveyancer and Property Lawyer 504 for a discussion of the Pringle case; see also De Beer Simultaneous Death: Arbitrary Fact 24.

95 Dollar "“Common Disaster': Confusion" August 2014 Sunlife Advisory Notes 1-7; see also Gjorgievska 21 July 2014 Time; Contributor 22 March 2016 BBC News; Rickards 3 January 2013 Listverse.

96 Belkin Death Before Dying 102-103.

97 Underwood v Wing supra 658-659. See also Digendra Kumar Roy Choudhury v Kuti Mian and Ors AIR $1944 \mathrm{Cal} 132$ \& 6: "Time being infinitely divisible, the fact of two persons dying at exactly the same moment of time is so highly improbable that the evidence relied upon to prove it must be looked at closely and critically".

98 Belkin Death Before Dying 100. From a medical perspective, it is possible to prove that people died seconds apart. See also Murray 1978 Annual Survey 364; Orji 2013 The Conveyancer and Property Lawyer 503.

99 [1945] AC 304.

100 See also Belkin Death Before Dying 100 and 103; Orji 2013 The Conveyancer and Property Lawyer 503-504. 
predeceased one another. ${ }^{101}$ In Re Lindop, Lee-Barber $v$ Reynolds a house was demolished by an exploding bomb in an enemy air raid. ${ }^{102}$ The bodies of the deceased, who had been asleep in the same bedroom, were found on the ground floor having sustained multiple injuries. The evidence showed that they must have been killed instantly. The two witnesses who found and examined the bodies were of the opinion that the deaths must have been simultaneous.

In the absence of clear evidence that one of the victims had survived the others, common law jurisdictions are "inclined to assume" that all victims died simultaneously while the civil law jurisdictions will revert to the applicable presumptions. ${ }^{103}$

\section{Sequence of related people's deaths is uncertain}

Most reported case law falls in the third category. This is probably because whenever disaster strikes the chaos that ensues often leaves one with very little evidence in respect of what the order of deaths was. ${ }^{104}$ It can either be that there is no or insufficient evidence, or that despite evidence it remains "uncertain". ${ }^{105}$ In Re Kennedy, a married couple had been killed when they drove off a pier in bad weather. The pathologist who had performed an autopsy on the bodies was unable to state for certain which of them had died first. In Re Mandin Estate the testatrix and her two daughters were murdered by her son. If it could be proved that the testatrix died before her minor daughters, her estate would have passed on to them before they also passed away seconds or minutes later. If the rights to the mother's estate had vested in the daughters, it would then devolve to their intestate heir (who happened to be their father, the testatrix's first husband). The sequence of their deaths remained uncertain. ${ }^{106}$ In Collins $v$ Bechal a similar situation arose when a mother and her only child were killed in an automobile accident. ${ }^{107}$ As there was no evidence to indicate the order of death, the child was presumed to have survived her mother. ${ }^{108}$ In In re Estate of Parisi, the bodies of a father and his daughter were found in

101 Author's own emphasis. See Ex parte Graham supra; Tucker $v$ Shreveport Transit Management Inc. supra with regard to the distribution of pension. Some jurisdictions use presumptions in this regard.

102 See Ex parte Chodos supra; Ex parte Graham supra; Digendra Kumar Roy Choudhury $v$ Kuti Mian and Ors supra.

103 The different approaches are discussed in an article to be published in De Jure 2017. In certain civil law codes provision is made for a presumption of "simultaneous deaths" while other jurisdictions still have presumptions based on seniority. The latter can either be that a certain sequence of death is presumed or that the "no survivorship" presumption applies. See also Olson v Estate of Rustad supra; Trushin 30 August 2013 Florida Probate Lawyer.

104 Author's own emphasis; see Orji 2013 The Conveyancer and Property Lawyer 504; Gray v Sawyer supra.

105 See Olson v Estate of Rustad supra; see also Trushin 30 August 2013 Florida Probate Lawyer, Conway and Bertsche 194413 Fordham LR 18ff. For SA law see Roeleveld 1970 Acta Juridica 33ff; Schoeman 1999 De Jure 111.

106 Par 3.

107 Conway and Bertsche 194413 Fordham LR 18.

108 Nathan 1966-1967 Tulane LR 42 refers to the presumption as a legal fiction. 
various stages of decomposition. ${ }^{109}$ It was determined that the father's death was due to natural causes and the daughter's death was ruled "accidental from salicylate intoxication". The death certificates reflect times of death as two minutes apart, which were the times their bodies were discovered. The Court held as follows:

"When there is no sufficient evidence that two individuals died other than simultaneously, each individual's property is distributed as if he or she had survived the other individual. Each individual's property passes to that individual's relatives and not to the other person's relatives. Thus, neither decedent inherits from the other".

In Olson v Estate Rustad the deceased was piloting a plane when it struck a television antenna and crashed, killing him and his passenger. There were no eye witnesses to the accident and a person sleeping in a trailer on the farmstead where the accident occurred, reported hearing an airplane flying low. ${ }^{110}$ The wreckage was discovered later that morning and both the deceased had been dead for some time. It was accepted that the victims had died simultaneously.

Testamentary clauses which refer to possible "simultaneous death" or which provide for situations where one "predeceased" the other, prove to be problematic. ${ }^{111}$ Maiden states the following: ${ }^{112}$

"Many clients ask us what happens when a couple or business partners die in the same accident. The order in which married couples die may be relevant. The Will of the first to die takes first effect. Depending on what it says inheritance may pass to the second to die or may bypass that person. This can be particularly relevant if the Wills of couples are not identical. The order of death may create an injustice because the parties may have anticipated that the younger person would survive the older person and have made Wills accordingly."

A case involving a disastrous accident where several lives were lost, is Tucker $v$ Shreveport Transit Management Inc. ${ }^{113}$ A couple who were riding a motorcycle was struck head-on by a truck. They both had valid wills and each provided that, in the event of simultaneous death, they would be deemed to have survived the other. The sequence of their deaths was

109 In re Estate of Parisi 765 NE 2d 123 (Illinois App 2002); see also Ex parte Graham supra; Gray v Sawyer supra; In re Estate of Moran 395 N E 2d 579, 77 Illinois 2d 147; Brundige v Alexander 547 SW 2d 232234 (Tenn 1976); Estate of Nancy Schweizer v Estate of Roland supra.

110 See also Estate of Villwock $v$ Olinger supra; Matter of Estate of Campbell where both spouses died intestate.

111 See Corbett et al The Law of Succession in South Africa 547; Greyling v Greyling supra 123F-H; Stephens v Beard supra; Murray 1978 Annual Survey 364; Orji 2013 The Conveyancer and Property Lawyer $501 \mathrm{ff}$.

112 Maiden "Wills and Succession Planning upon Simultaneous Deaths" 16 July 2013 https://macdonnells.com.au/wills-and-succession-planning-upon-simultaneous-deaths (accessed 20-01-2017).

113 Each will contain reciprocal bequests of the both spouses' entire estate to the survivor and alternative bequests to the testators' children in the event that the spouses were to die in a common disaster. See also Belkin Death Before Dying 100 and 103 and Nathan 1966-1967 Tulane LR $39 \mathrm{ff}$. 
questioned as the provisions in the wills were at odds with the detailed retirement plan that they had prepared. ${ }^{114}$ The most recent reported case in South Africa where "simultaneous death" was at issue is the 1978 case of Greyling $v$ Greyling. ${ }^{115}$ A husband and wife were killed in a car accident. Their joint will have contained a provision to the effect that, if they died "simultaneously", their estate had to devolve to their respective nominated heirs. ${ }^{116}$ According to the evidence, the husband probably lived longer than his wife. The Court had to interpret the words "to die simultaneously" used in their wills to establish whether it meant that the deaths occurred as the result of a single incident, irrespective of the fact that there might have been a difference in the exact time at which each had died. ${ }^{117}$ A later case, that was not pursued further, is Smith $v$ Pretorius where legal action was instituted based on the alleged "simultaneous deaths" of a mother and her son. ${ }^{118}$ The will of the son provided for charities as beneficiaries "if" his mother predeceased him while the will of the mothers benefitted her brother "if" her son predeceased her. The mother's brother claimed that she had survived her son. ${ }^{119}$

\section{5}

\section{HOMICIDE CASES AND SIMULTANEOUS DEATHS}

There have of late been several reported cases that deal with homicides that led to lives having been lost simultaneously. These cases comprise of instances of domestic violence, manslaughter, suicide bombings, shootings and stabbings. ${ }^{120}$

In re Estate of Moran, a mother and her son died as the result of carbon monoxide poisoning while sitting in a parked car that was left running in an

114 The retirement plan's beneficiary designation was interpreted naming his wife because she had not died before him. See also Collins v Becnel supra; Re Kennedy; Re Fair and Matter of Estate of Campbell where a husband and wife, died simultaneously in a boating accident; Roeleveld 1970 Acta Juridica 31-33; Trushin 30 August 2013 Florida Probate Lawyer.

115 In Estate Greenacre v Brett supra the alternative provision fails to take effect. The case was strongly criticised by Murray 1978 Annual Survey 368. See also Re Rowland: Smith $v$ Russell supra.

116 Murray 1978 Annual Survey 364ff. See also West 21 May 2015 Ghostdigest

117 Ibid.

118 Smith v Pretorius supra $\S 4$. The surname is misspelled as "Pretorious" instead of Pretorius. See also De Beer Simultaneous Death: Arbitrary Fact 10. The Master has accepted that R's estate should be dealt with as an intestate matter.

119 It was claimed that the mother who was sitting behind her son (the pilot) lived for a few seconds after R's death, and therefore inherited his estate in terms of his will, before she passed away. This matter was withdrawn due to personal circumstances of the claimant but could have had implications for the insurance industry, succession law and the medica industry. See De Beer Simultaneous Death: Arbitrary Fact 10.

120 See Grossman "Murder, Suicide, and the Fight over an Inheritance" 11 November 2014 Verdict https://verdict.justia.com/2014/11/11/murder-suicide-fight-inheritance (accessed 2016-05-30); Salib "Effect of 11 September 2001 on Suicide and Homicide in England and Wales" 1832003 The British Journal of Psychiatry 207-212; Melez, Avşar, Başpina, Melez, Şahin and Özdeş "Simultaneous Homicide-suicide: A Case Report of Double Drowning" 2014 J Forensic Sci 1432-5. In Re Mandin Estate a son was responsible for the murders of his mother and his sisters. 
enclosed garage. ${ }^{121}$ In Leete $v$ Sherman, a couple died of carbon monoxide poisoning. Their bodies were discovered in their car. ${ }^{122}$ The husband's daughter (from a previous marriage) questioned the sequence of their deaths. The husband had a will providing for the event where his wife has not survived him for a period of more than thirty days. The Court ruled that there was no clear and convincing evidence to show that he predeceased his wife. The property was divided between their respective estates. In Stephens $v$ Beard a man shot and killed his wife. That same night he committed suicide. According to the death certificate, the time of her death was two hours before he died. Their wills provided for specific cash bequests to individuals if they both died in "a common disaster" or "under circumstances making it impossible to determine which died first". The Court determined that they had died in a common disaster. ${ }^{123}$

In the Estate of Benoit, the order of deaths was questioned after Canadian pro wrestler Chris Benoit killed his wife and their seven-year-old son and then shot himself. A dispute arose between his two children from a previous marriage and the family of his murdered wife. If his son had died first, the estate would pass to his deceased mother (as the father was unworthy as the killer) and it would then pass from her to her family. The case was settled out of Court. ${ }^{124}$ Matter of Estate of Hughes also concerns the sequence of deaths after a man, who had shot and killed his wife, committed suicide. ${ }^{125}$ The Court ruled that the wife survived the husband and that the property devolves to her heirs. ${ }^{126}$ Jollimore Estate $v$ Nova Scotia (Public Archives) ${ }^{127}$ regards a case where a son murdered his mother and then committed suicide. The mother bequeathed her estate to a charity in case her son predeceased her. The Court had to decide whether the son technically can be considered to have "predeceased" (as stipulated in the will) as he first had to have murdered her and then had committed suicide. The Court ruled that the mother's will took effect (as if her son had predeceased her) and that the charity will inherit. ${ }^{128}$

In the South African case $S \vee D D$, the evidence was that the deceased victims were the parents and sister of a minor boy, who had shot and killed them. The parents left a mutual will which made provision for every possible

121 In re Estate of Moran 395 N E 2d 579, 77 Illinoi 2d 147; see also Re Pechar (Deceased): Re Grbic (Deceased) [1969] NZLR 574 a case on the survivorship in a common disaster where a man had killed his wife and In the Matter of the Estate of Byron Miller (deceased) Supreme Court of Mississippi [no 2002-ca-00231-sct] which involves the tragic murder/suicide of a husband and wife where the order of death could not be determined.

122 See also United Trust Co v Pyke (1967) 199 Kansas 18427 P 2d 67 at 72-73 where a man shot his wife.

123 See $\S \S 2.02-2.03$ of the decedents' wills.

124 See also the reference to Estate of Benoit 2014-377871 in 8 May 2015 New York Law Journal.

125 See also Aggrawal 20053 Encyclopedia of Forensic and Legal Medicine 216ff.

126 The doctor's opinion was that most likely the husband (killer) died instantly.

1272011 Supreme Court of Nova Scotia (Canada NSSC) 218. See $\S 15$ and 16.

128 Recently the crash of the Germanwings-aircraft was also identified as suicide act by the pilot. See also Fotrell "Airline Crash Compensation for Victims' Families can vary wildly" 27 May 2015 Personal Finance where the question was asked "[a] pilot had deliberately crashed a plane, does a court take this into account". 
scenario except for the situation where one of their potential heirs becomes unworthy. From the evidence in the criminal case, it became clear that the mother was shot first, thereafter the father and the minor sister last. ${ }^{129}$ The sequence of death was not really in dispute as the survivor became an unworthy heir.

\section{RELATED PROBLEMS}

Every so often, when people die in the same incident (common calamity) the sequence of death not only becomes a concern of the law of succession, but other related legal problems might also have an indirect impact on the division of the estates. ${ }^{130}$ Some of these other claims include (i) wrongful death claims, ${ }^{131}$ as well as (ii) insurance and other policy claims. A wrongful death claim was instituted in the case Collins $v$ Becnel where a woman and her major daughter were simultaneously killed in an automobile accident. The defendants contended that the presumption of survivorship of "commorientes" found application to determine the beneficiaries of wrongful death claims and had to be applied. ${ }^{132}$ It was held, however, that the presumption of survivorship was "not applicable" to determine beneficiaries of wrongful death claims. ${ }^{133}$ In Olson $v$ Estate Rustad a claim for wrongful death institute on behalf the children of the passenger in a Cessna aircraft was also dismissed. ${ }^{134}$ De Vries $v$ Road Accident Fund deals with the quantification of a claim where the parents died simultaneously in a vehicle accident. ${ }^{135}$ It was accepted that the deceased were passengers in a vehicle involved in a motor vehicle collision on 3 March 1994 in which they sustained fatal injuries. The accident was caused solely by the negligence of the driver of the other vehicle involved (the "insured driver") and it was

129 They could be regarded as "commorientes" within the meaning of "they all died simultaneously in the same calamity. Phillips 2010 California Law Journal, also refers to victims of the Jonestown suicide in Guyana. See Contributor "What was the Jonestown Massacre?" Updated 6 February 2017 http://history1900s.about.com/od/1970s/p/ jonestown.htm (accessed 2017-02-17): "On November 18, 1978, Peoples Temple leader Jim Jones instructed all members living in the Jonestown, Guyana compound to commit an act of "revolutionary suicide," by drinking poisoned punch. In all, 918 people died that day."

130 This aspect is not discussed in detail in this contribution. See Contributor "Life Insurance and the Presumption of Death" 19376 Fordham LR 91. See also De Wet "Plane 'shouldn't have flown'" 12 October 2006 News24; De Beer Simultaneous Death: Arbitrary Fact 4-5.

131 See De Vries $v$ Road Accident Fund [2011] ZAWCHC 215; see also Andreano "Understanding Wrongful Death and Survival Action" 201510310 Illinois Bar Journal.

132 See also Re Rowland: Smith v Russell supra; Mee 2005 Northern Ireland Legal Quarterly 176 for a discussion of the case.

133 See Sherwood "Application of Presumptions of Survivorship among Commorientes to Determine Beneficiaries" 197650 Tulane LR 441ff who discusses the case and summarize it.

134 The estate of the pilot argued that Olson could not show Hanna (the passenger) was injured before the pilot died, and therefore, both the wrongful death and survivor claims were barred under the non-claim provisions of the Probate Code.

135 De Vries v Road Accident Fund supra; see also United Trust Co v Pyke supra 72-73 where the appeal involves claims of inheritance, joint tenancy survivorship, and proceeds under life insurance contracts in the estates of two decedents, husband and wife, and to collect damages for the wrongful death of $D$ by the alleged wilful and intentional shooting of her by I, who then committed suicide. 
common cause between the parties that, to the extent that the plaintiffs suffered any damages, the defendant was liable in its capacity as the insurer of the insured driver. ${ }^{16}$

Another legal problem that has arisen in the context of "simultaneous deaths", relates to insurance policy distributions and insurance disputes. ${ }^{137}$ Generally, when an insured individual dies, the policy proceeds go to the primary beneficiary, but when the insured and the primary beneficiary both die at the same time, it can create complex legal problems to establish to whom the proceeds of the policy should go. In the Janus $v$ Tarasewicz case, the policy was channelled through the wife's estate to her heirs as she had survived her husband. In McCurtis $v$ Life Ins Co of North America, ${ }^{138}$ the family car was struck by another vehicle. One of the victims was covered by an employee benefit plan, which included a term life insurance plan and an accident plan that contained coverage for accidental death. The right to these earnings was the subject of the dispute. ${ }^{139}$ In Re Fair, the deceased was insured and his wife was named as beneficiary. The Court had no difficulty in concluding that the money representing the proceeds of the insurance policies should be paid to the administrator of the wife's estate. ${ }^{140}$

\section{CONCLUSION}

As succession is conditional on survivorship, no person can succeed as an heir or legatee unless he or she survives the deceased person. ${ }^{141}$ Where people, who are each other's heirs, be it under a will or intestate, are killed in the same disaster the issue of survivorship may be pivotal in determining the order of succession. ${ }^{12}$ If, however, one of the deceased had survived the other (by as little as a few seconds), the survivor can succeed to the first

36 Par 10.

137 See De Vries v Road Accident Fund supra; Estate of Villwock v Olinger supra; McCurtis v Life Ins Co of North America 849 F Supp 1141 (S D Miss 1994); Tracy and Adams 194038 Michigan LR 803; Conway and Bertsche 194413 Fordham LR 32; Roeleveld 1970 Acta Juridica 41. See also Sentell "The Missing Insured and the Life Insurance Death Claim" 2004 54(2) Federation of Defence \& Corporate Counsel Quarterly 198.

138 McCurtis v Life Ins Co of North America supra par 11: "Simultaneous" is not specifically defined ... but case law establishes that the term is to be given its "ordinary and accepted meaning," that is, "occurring at the same time." The Court refers to Estate of Villwock $v$ Olinger supra (quoting Webster's Third International Dictionary 2122). See also Smith $v$ Smith supra.

139 Par 13: "Plaintiffs have specifically admitted that if Mary McCurtis was the last to perish in the automobile accident, they would have no rightful claim to the insurance proceeds."

140 See Dollar August 2014 Sunlife Advisory Notes 1-7. In Tucker $v$ Shreveport Transit Management Inc. supra the retirement plan's designated beneficiary was interpreted as naming his wife because she had not died before him and those proceeds went to his wife's estate and, ultimately, to her three children.

141 Corbett et al The Law of Succession in South Africa 5 and 574. See Ex parte Wessels and Venter NNO: In re Pyke-Nott's Insolvent Estate 1996 (2) SA 677 (O).

142 West 21 May 2015 Ghostdigest. 
dying but the first dying cannot succeed to the survivor. Where both died at exactly the same moment neither can succeed the other. ${ }^{143}$

Disputes regarding the sequence of deaths have become common and do not only impact on the law of succession but in general, on the administration of estates, insurance policies, property law claims, pension benefits and wrongful death actions. ${ }^{144}$ The Court has to scrutinise the facts of the specific deaths to establish if there is any indication that one deceased may have died later (no matter how short a time is involved). To investigate such matters could require expert evidence and might incur costs. ${ }^{15}$

Several aspects have contributed to the recent increase of simultaneous deaths due to the change in times and conditions over the past 2000 years. ${ }^{146}$ One factor is the advances made in transportation and this increase in traffic as it has led to an increased number of accidents. ${ }^{147}$ Trushin explains the dilemma as follows: ${ }^{148}$

"Yet, the advent of the train, automobile, and airplane brought an increase in deaths of closely related persons in common disasters, particularly husbands and wives. In these unique situations, estates were dislocated, trusts were disturbed, and the law of descents was frequently shunted off its regular course. The legal question thus arose: When a person dies simultaneously with his or her heir or devisee, does the heir or devisee succeed to the person's property, so the property becomes part of the heir or devisees estate?"

Furthermore, recent catastrophes show that there is a definite increase in incidents of natural disasters. Worldwide climatic trends such as global warming and threats that stem from ozone damage also contribute to simultaneous deaths. ${ }^{149}$ Another aspect is the progresses made in medical knowledge which has made it easier to present proof of the exact moment of death. Orji argues that advances in medical technology have allowed life to be "prolonged artificially" following an accident in ways that were not possible in earlier historical periods.

143 Gray v Sawyer supra; In re Pringle; Orji 2013 The Conveyancer and Property Lawyer 504; De Beer Simultaneous Death: Arbitrary Fact 24.

144 See Roeleveld 1970 Acta Juridica 37; Murray 1978 Annual Survey 365; Schoeman 1999 De Jure 181; Van Heerden, Cockrell and Keightley Boberg's Law of Persons and Family (1999) 56; Corbett et al The Law of Succession in South Africa 5; De Waal and Schoeman-Malan

145 lbid Law of Succession 11-12; West 21 May 2015 Ghostdigest.

146 Nathan 1966-1967 Tulane LR 39ff; Tracy and Adams 194038 Michigan LR 801; Mee 2005 Northern Ireland Legal Quarterly 171; Gallanis in Helmholz and Sellar The Law of Presumptions 200.

147 Gallanis in Helmholz and Sellar The Law of Presumptions 200; Nathan 1966-1967 Tulane LR 43; Corbett et al The Law of Succession in South Africa 547.

148 Trushin 30 August 2013 Florida Probate Lawyer; see also Mee 2005 Northern Ireland Legal Quarterly 171ff; De Beer Simultaneous Death: Arbitrary Fact 14.

149 See Goldberg 14 July 2014 The Guardian.

150 Orji 2013 The Conveyancer and Property Lawyer 506: "While the simultaneity of death is sometimes a mute question in law, there will be instances in which rights of high importance will depend on the certainty of who died before the other". 
The Courts are called upon in estate disputes to determine the order of deaths and to establish whether the exact sequence can be determined, or not. Whenever the order of death can be established accurately, the distribution of the estates will follow the sequence of deaths. If the order cannot be established the departed are either "regarded" as having predeceasing each other (as no one survives the other), or surviving each other resulting in them being incapable of inheriting from one another.

South Africa is exposed to high rates of simultaneous deaths, especially road accidents, murders and attacks on civilians, and despite daily media reports of people dying in the same disaster, there has been only a hand full of reported Court cases on this topic. ${ }^{152}$ However, globally there is an increase in reported cases and investigation on the topic. ${ }^{153}$ South Africa to a large extent seems to have escaped all the confusion surrounding the "commorientes" principle. ${ }^{154}$

To prevent ambiguity or undesirable results, testators wishing to provide for the contingency of death (in the same calamity or catastrophe) should be informed during the will-making process of the possible outcomes of testamentary clauses or "common calamity clauses". ${ }^{155}$ Many estateplanning experts recommend that the use of the word "predeceased" or the words "if we die simultaneously" should be avoided and that another type of clause that requires the deceased's beneficiaries to survive him of her for a minimum period of time before they can receive your assets, should rather be considered to prevent assets from passing through a co-testator or a heir estate. ${ }^{156}$

151 Civil and common law jurisdictions might follow different approaches once the order of death cannot be established.

152 See fn 5 and 31 above.

153 Also on the medical terrain: Belkin Death Before Dying 98ff; Wijdicks http://dx.doi.org/10.1093/brain/awu124.

154 West 21 May 2015 Ghostdigest. Usually the Courts would have followed the Roman Dutch common law. De Beer Simultaneous Death: Arbitrary Fact 8.

155 See also Corbett et al The Law of Succession in South Africa 548; see also Aubrey-Smith v Hofmeyr 19731 SA 655 (C).

156 Cussen https://www.fool.com/investing/2017/01/30/protect-your-estate-plan-with-a-titanicclause.aspx: "If both members of the couple die at once, or if it's impossible to determine which of them died first, then this clause will kick in and name one of them as the first to die". One of the ways to overcome this sort of difficulty is to provide in Wills that for example, "I leave everything to my Wife if she survives me by 30 days". Generally speaking, if people are going to die from an accident they will do so within that short period of time. That avoids the confusion that might arise through simultaneous or uncertain order of death and also avoids the need to pass everything from one estate to the estate of another person who has already died. 